\title{
THE EFFECT OF ADOPTION OF IFRS BASED ACCOUNTING STANDARDS: INDIAN EVIDENCES OF ENHANCED VALUE RELEVANCE AND UNIFORMITY
}

\author{
Somnath Banerjee \\ Associate Professor \\ Commerce \& Management \\ St. Xavier's University, Kolkata, India \\ E-mail: bjsomnath02@gmail.com \\ Satyajit Dhar \\ Professor \\ Department of Business Administration \\ University of Kalyani, West Bengal, India \\ E-mail: satyajitdhar@yahoo.co.in \\ Anirban Dutta \\ Assistant Professor \\ Department of HSS \\ NIT, Agartal, India \\ E-mail: anirbandutta.som@gmail.com
}

Received: July 26, $2021 \quad$ Accepted: September 06, $2021 \quad$ Online Published: September 23, 2021

DOI: 10.46281/ijafr.v8i1.1353

URL: https://doi.org/10.46281/ijafr.v8i1.1353

\begin{abstract}
This study examines how relevant the accounting information was for the value of the firm prior to 2016, when India had the indigenous Accounting Standards, and after 2016 when India adopted new accounting standards known as IND-AS, which were the convergence standards mostly in line with IFRS. As an extension to this, we have performed another round of analysis to observe whether the enhanced value relevance is symmetrically distributed among big and small firms. We have used the price regression model of (Barth et al, 2008) on 1770 firm-years data of Indian firms and applied panel data analysis. We have found $66 \%$ adjusted $R^{2}$ under OLS method for the period prior to 2016 and $78 \%$ for the post-change period. Further to this, big and small firms, in the new regime, have shown 84\% and $89 \%$ adjusted $R^{2}$. From the results, we have found substantial improvement in value relevance of accounting information in the IND-AS period. We have also found that the enhanced value relevance is uniformly distributed across firms irrespective of firm-size.
\end{abstract}

Keywords: Value relevance, EPS, BVPS, IND-AS, Fixed Effect, Random Effect, OLS.

JEL Classification Codes: M41. 


\section{INTRODUCTION}

The effect of accounting choices on the values is fundamental to positive accounting theory. Earlier studies have shown the empirical researches on debt-equity ratio, managerial compensation (bonus plans) and political costs and have significantly established that each one of these can affect firm value as they depend on accounting choices. In line with the contemporaneous concepts, the historical cost accounting and fair value accounting represent accounting choices which affect taxes and firm-value. The relevance of value of accounting information is an important and pivotal concept in our research. It is argued that IFRS adoption improves quality of financial information and thus facilitates discovery of value. Our study explores the effect of IFRS adoption on value relevance, in an emerging economy like India.

The MCA (Ministry of Corporate Affairs) in India has issued Indian Accounting Standards (abbreviated as Ind-AS) in consultation with Accounting Standard Board of the Institute of Chartered Accountants of India (ICAI) and NACAS (National Advisory Committee on Accounting Standards). Adoption of Ind-AS was mandated from 2016-17 in phase-wise manner. Indian companies have adopted Ind-AS which is convergence standard in line with IFRS. Some points as argued by Gjerde et al. (2011) are very similar and relevant in Indian scenario like Indian GAAP (Generally Accepted Accounting Principles) has also carried with it, the legacy of an Anglo-European touch which made Indian accounting standards more focussed on the income (earnings) side and less on the balance sheet whereas the US GAAP exercises more impactful focus on the balance sheet. The earlier Indian standard weighted more emphasis on tax based and creditor based reporting and the new paradigm is all about balance sheet and valuation based approach. Erstwhile Indian GAAP had difference of approaches with IFRS on many issues for example, revenue recognition, balance sheet (valuation and presentation), correction of fundamental errors, derivatives and other financial instruments - measurement of hedges of foreign equity, comprehensive income, business combination and stock issue expenses. Adoption of Ind-AS in India in that sense is a major change in the accounting environment.

Our sample consists of data of closing stock-price, earnings per share and book value per share from FY 2011-12 to 2019-20 for a large sample of listed Indian firms, which are the remaining ones after eliminating banks and financial institutions (as they are yet to adopt the new standards in the fullest extent), from BSE-500 Index which is the most followed broad-based index in India. The entire set of data has been divided into four different sets which represent the association of EPS (Earnings per share - the measure for earnings related accounting information) and BVPS (Book value per share - the measure of balance-sheet value) with stock prices, before and after the adoption of Ind-AS. Based on the points of distinguished differences in the accounting system of India and the EU and the US, it is of high interest to identify 1) the extent of value relevance of accounting information in India before the adoption of Ind-AS and ii) after the adoption of Ind- AS, India, being an emerging economy. As an extension to this study, we have also observed whether the enhanced effect of accounting information on stock prices are similar in case of big firms with very extensive analyst-following and the small and medium firms without having that.

Our study is important for the individual and institutional investors in India and other countries as the results of this study provides the answer for ' how far accounting information can predict stock prices in India' as compared with some of the other countries. The FIIs may use the regression coefficients of the best model for computing fair values of stocks of their choice. Our study is unique as it enquires further to the study of Clarkson et al. (2011) which proved statistically that adoption of IFRS had significantly reduced asymmetry of financial reporting and information, and finds out the answer for 'whether the effect of enhanced value relevance is similar in case of small and large firms'. As a basis of classification, we have taken big firms which are placed in leading indices and the other firms (which are not included in the indices) to understand the impact of new accounting regime on reduction of asymmetry in financial information in big firms and the others. The entire paper is divided into five sections namely introduction; literature review; model, sample and data; methodology and results and discussion \& conclusion. 


\section{LITERATURE REVIEW}

Prior studies in this area have mostly focussed on 1) adoption of IFRS and the value relevance of accounting information in the perspective of various countries ,2) persistence studies of value relevance over a long stretch of time, 3) fundamental conceptualization of value relevance of aggregate earnings, 4) value relevance in firms with different asset structures and the effect of aggregate or disaggregated components of earnings on value relevance over a period of time, 5) impact of models on value relevance and 6) value relevance of other firm specific factors like dividend pay-out and audit quality.

Kumari and Mishra (2020); Alali and Foote, (2012) and Filip and Raffournier (2010) are the studies based on emerging markets like India, Abu Dhabi and Romania respectively. All of the authors have focussed on the value relevance of accounting information in the backdrop of adoption of IFRS except the first one, which has thrown light on the emergence of intangible intensity of firms and the presence of value relevance of earnings and earnings components. The IFRS based studies have shown relevance of accounting information in post IFRS time in Romania and Abu Dhabi. Clarkson (2011) have studied the effect of IFRS adoption in EU countries and Australia. The paper has observed that nonlinearity of information is negative after the switch to the new regime which proves that financial statements have become more comparable. Cordazzo and Rossi (2019) have studied about the impact of value relevance of intangibles in Italy. Kadri et al. (2009) have conducted a study in Malaysia and clinched some important information about relevance of book values after IFRS regime. They have argued that after adoption of IFRS, there is more relevance of book value than the earnings and this is because the new regime places more emphasis on book values in valuation issues. Okafore et al. (2016) have argued that some firms outside Europe had IFRS adoption before it was made mandatory and this shows the importance of studying the effects of IFRS adoption in non-European countries. The study is based on a sample of Canadian firms listed in other country's stock exchange (USA) and other Canadian firms which were not listed outside. The data of US-listed firms as per US-GAAP and Canadian firms after adoption of IFRS have shown more relevance of accounting information in post adoption time. Veith and Werner (2014) have shown efficacies of country-specific studies of value relevance. Gjerde et al. (2011) have presented a study of value relevance in Norway over a prolonged period of time and have opined about persistence of it over the period. Harakeh et al. (2018) have conducted a study in UK and France. France being highly divergent from IFRS and UK being less, the authors have argued that adoption of IFRS reduces the information asymmetry and hence a country with more divergence previously, observes an enhanced dividend pay-out. Lee and Lee (2013) have researched on the issue of big auditors in Taiwan. They divided the entire sample into firms with big auditors and the firms without big auditors and found out the significance of estimated coefficients and concluded that big auditors enhance the value relevance. Thijssen and Iatridis (2016) have conducted a similar research about value relevance of US GAAP and IFRS in a study of Canadian firms.

Onali et al. (2017) have shown a comparison of pooled OLS and the random effect vis- a-vis the fixed effect models on the significance of value relevance research and found the industry fixed effect to be the useful one.

Kim and Ryu (2018) have discussed about the impact of accepting IFRS in the context of Korea and have very interestingly distinguished the perspective of the study from most of the others, by looking at the reduction of cost of equity in Korea after the new accounting paradigm. This is impacted concept which opines that accounting choice affects values within firm and some firm values affect the perception of the investors. In a situation where the accounting choice does not affect values, the information of choice would be of no relevance to the investors. Avwokeni (2018) has focussed on the issue of future prospects of firms and have presented a study on how far these prospects are considered by investor in the form of a premium. This study focuses on the general information perspective and value relevance of those and the future prospects as well. The study has been conducted in the context of Nigeria, once with the domestic disclosures and after that, with IFRS compliance and found notable changes after IFRS adoption. Bepari (2015) have studied about the impact of global financial crisis on the value relevance of book value and earnings in Australia. He has argued in line with many other authors that book value becomes more relevant when earnings become poorer under the new regime of 
IFRS. In this paper, he has also looked into the aspect of incremental relevance of the period other than crisis.

The sample, methodology and findings are discussed in the forthcoming sections.

\section{Price regression models with current values}

\section{MODEL, SAMPLE AND DATA}

Book values of assets and earnings are the two major accounting pieces of information which are expected to affect firm value. The firm value is measured by the market price of stock in most of the cases. Clarkson et al. (2011) have shown the extent of value relevance in a wide range of EU countries and Australia as well. Considerable relevance of earnings and book values has been observed in his study. To test the extent of value relevance of accounting information, we have used the Price Regression Model (Barth et al., 2008) which is given below in details.

$P_{i t}=a+b_{\text {BVPS }}$ it $+c$ EPS $_{i t}+e_{i t}$ equation (i)

Where $\mathrm{P}$ it is the closing price of the $\mathrm{i}^{\text {th }}$ stock at yeat $\mathrm{t}$ where $\mathrm{i}=1,2,3, \ldots \ldots . . \mathrm{N}$ firms and $\mathrm{t}=$ $1,2,3, \ldots . \mathrm{T}$ is the time. EPS and BVPS are earnings per share and book value per share. $\mathrm{a}, \mathrm{b}$ and $\mathrm{c}$ are the regression coefficients and e is the error term.

\section{The Sample and the Descriptive}

The entire sample consists of 1770 firm years of Indian firms which includes 352 firms' data for the period of 2012-2020. For the purpose of observing the effect of the new standards, the data has been divided into two panels namely A and B. A includes all the firms' data for 2012-2020 which is before the adoption of new standards while B corresponds to the period after the new standards were adopted. The sample is constructed from BSE 500 index which is a broad based stock market index in India.

Panel $\mathrm{C}$ consists of big firms which are included in the leading indices of Indian stock market (SENSEX and NIFTY) and corresponds to post adoption of new standards. Panel D comprises of small and off-the-index firms. $\mathrm{C}$ and $\mathrm{D}$ are used to observe the symmetry or asymmetry of the effect of adoption of new standards on big and small firms. In C and D, the divergence of mean and median is much lower than the other panels. This is because of consistency effect of smaller part of the larger data. The comprehensive summary of all the panels is given in Table 1.

Table 1. Descriptive statistics of panel data

\begin{tabular}{|c|c|c|c|c|c|c|c|c|c|}
\hline Panel & Details & Variables & Min & $\begin{array}{l}1^{\text {st }} \\
\text { Ouartile }\end{array}$ & Median & Mean & $\begin{array}{l}3^{\text {rd }} \\
\text { Quartile }\end{array}$ & Max & Count \\
\hline \multirow[t]{3}{*}{ A } & \multirow{3}{*}{$\begin{array}{l}\text { Firm years for } \\
2011-2016 \text {. } \\
\text { (prior to the new } \\
\text { standards) } \\
* * \text { A is used to } \\
\text { observe the } \\
\text { persistence of } \\
\text { value relevance } \\
\text { prior to the new } \\
\text { standards. }\end{array}$} & $\begin{array}{l}\text { Closing } \\
\text { Price }\end{array}$ & 4.52 & 100.90 & 267.28 & 747 & 645.86 & 38809.95 & \multirow[t]{3}{*}{1770} \\
\hline & & EPS & -166.7 & 4.645 & 12.655 & 31.296 & 31.370 & 3936.630 & \\
\hline & & BVPS & -74.30 & 47.36 & 104.31 & 205.05 & 219.05 & 16885.09 & \\
\hline \multirow[t]{3}{*}{ B } & \multirow{3}{*}{$\begin{array}{l}\text { Firm years for } \\
2016-2020 \text {. } \\
\text { (post adoption of } \\
\text { the new } \\
\text { standards) }\end{array}$} & Closing & 2 & 157.3 & 390.7 & 1326.4 & 968.0 & 72300.7 & \multirow[t]{3}{*}{1415} \\
\hline & & & & & & & & & \\
\hline & & EPS & -129.09 & 5.63 & 14.78 & 42.385 & 33.410 & 3429.69 & \\
\hline
\end{tabular}




\begin{tabular}{|c|c|c|c|c|c|c|c|c|c|}
\hline & $\begin{array}{l}* * \text { B is used to } \\
\text { observe the } \\
\text { persistence of } \\
\text { value relevance } \\
\text { after the new } \\
\text { standards and } \\
\text { the impact of it. }\end{array}$ & BVPS & -138.05 & 59.59 & 128.50 & 317.11 & 254.78 & 20304.52 & \\
\hline \multirow[t]{3}{*}{$\mathrm{C}$} & \multirow{3}{*}{$\begin{array}{l}\text { Big Firms for } \\
2016-2020 \text {. } \\
\text { (after the new } \\
\text { standards) } \\
* * \text { used to } \\
\text { observe the } \\
\text { effect of new } \\
\text { standards on big } \\
\text { firms. }\end{array}$} & $\begin{array}{l}\text { Closing } \\
\text { Price }\end{array}$ & 20.8 & 253.9 & 561.1 & 1933.3 & 1445.1 & 28337 & \multirow[t]{3}{*}{160} \\
\hline & & EPS & -43.99 & 11.30 & 25.64 & 67.74 & 55.82 & 793.32 & \\
\hline & & BVPS & 22.42 & 97.36 & 195.16 & 417.05 & 492.28 & 3190.15 & \\
\hline \multirow[t]{3}{*}{$\mathrm{D}$} & \multirow{3}{*}{$\begin{array}{l}\text { Small and } \\
\text { medium Firms } \\
\text { for 2016-2020. } \\
\text { (after the new } \\
\text { standards) } \\
* * \text { used to } \\
\text { observe the } \\
\text { effect of new } \\
\text { standards on } \\
\text { small firms. }\end{array}$} & $\begin{array}{l}\text { Closing } \\
\text { Price }\end{array}$ & 2 & 184 & 460.3 & 3193.3 & 1214.4 & 72300.7 & \multirow[t]{3}{*}{164} \\
\hline & & EPS & -10.810 & 5.827 & 13.685 & 121.922 & 44.715 & 3429.69 & \\
\hline & & BVPS & -19.37 & 48.36 & 116.67 & 879.53 & 272.18 & 28304.52 & \\
\hline
\end{tabular}

Source: Authors' own construction from the output of R

\section{METHODOLOGY AND RESULTS}

\section{Results from Panel A \& B and Analysis}

We have used panel linear model for the regression of closing price with EPS and BVPS. As described in Section 3, we have tried to estimate the regression coefficients of EPS and BVPS using Panel A and Panel B. We have used three different methods of regression (Ordinary Least Squares - OLS, Fixed Effect- FE and Random Effect- RE) for each Panel and have observed the changes in Adjusted $\mathrm{R}^{2}$. We have accepted the model with maximum value of Adjusted $\mathrm{R}^{2}$ as our principal objective is to observe the best case which shows the value relevance of EPS and BVPS on the Closing Price. The results of the regressions are shown in Table 2 and Table 3.

Table 2. Panel A \& B Result Summary

\begin{tabular}{|c|c|c|c|c|}
\hline \multicolumn{5}{|c|}{ Panel A Results } \\
\hline & Intercept & EPS $_{\text {it }}$ & BVPS $_{\text {it }}$ & $\mathrm{R}^{2} \& \operatorname{Adj} \mathrm{R}^{2}$ \\
\hline Coefficients & $\mathrm{A}$ & $\mathrm{C}$ & $\mathrm{B}$ & \\
\hline OLS & 265.308 & 6.22 & 1.39 & .66 \\
\hline Sig & $.000 * * *$ & $.000 * * *$ & $.000 * * *$ & $.65 \mathrm{adj}$ \\
\hline $\mathrm{FE}$ & - & 2.11 & 2.64 & .52 \\
\hline Sig & - & $.001 * *$ & $.000 * * *$ & .40 \\
\hline $\mathrm{RE}$ & 211.177 & 3.771 & 2.03 & .56 \\
\hline Sig & $.000 * * *$ & $.000 * * *$ & $.000 * * *$ & $.56 \mathrm{adj}$ \\
\hline \multicolumn{5}{|c|}{ Panel B Results } \\
\hline & Intercept & $\mathrm{EPS}_{\text {it }}$ & BVPS $_{\text {it }}$ & $\mathrm{R}^{2} \& \operatorname{Adj} \mathrm{R}^{2}$ \\
\hline
\end{tabular}




\begin{tabular}{|l|l|l|l|l|}
\hline Coefficients & \multicolumn{1}{|c|}{$\mathrm{A}$} & $\mathrm{C}$ & $\mathrm{B}$ & \\
\hline OLS & $394 . .0111$ & 19.43 & .343 & .78 \\
\hline Sig & $.000 * * *$ & $.000 * * *$ & $.000 * * *$ & .78 adj \\
\hline FE & - & 1.97 & -.48 & .015 \\
\hline Sig & - & $.001 * * *$ & $.001 * * *$ & -.31 adj \\
\hline RE & 566.927 & 9.86 & 1.07 &. .44 \\
\hline Sig & $.000 * * *$ & $.000 * * *$ & $.000 * * *$ & .44 adj \\
\hline
\end{tabular}

Signif. codes: 0 ‘***’ $0.001^{\text {'**’ }} 0.01^{\text {'*’ }} 0.05^{\prime}$ '?

Source: Authors' construction from the output of R

For panel A and B, the OLS method is most efficient. In panel A, all the coefficients are accepted with 100 percent confidence levels. In panel A, the t values of the intercept, EPS and BVPS are 8.49, 8.85 , and 9.17 respectively which confirms the significance of the coefficients in the OLS model. The Adj $\mathrm{R}^{2}$ of OLS method is $66 \%$ which is highly accepted. The RE model could generate 56 percent Adj $\mathrm{R}^{2}$ only. In Panel $\mathrm{B}$, the OLS method has produced highly significant coefficients. In panel $\mathrm{B}$, the $\mathrm{t}$ values of the intercept, EPS and BVPS are 7.22, 25.46 and 3.49 respectively in the OLS model which makes them highly significant. Substantial improvement of Adj $\mathrm{R}^{2}$ from $65 \%$ to $78 \%$ is observed in Panel B which is an improvement of $20 \%$. In both panels, RE model also generated significant coefficients and Adj $R^{2}$ s but they were far behind the OLS method. Coefficients of BVPS have smaller values and they are biased towards zero which clearly indicates EPS as the most important variable for prediction in price regression models.

\section{Results of Panel C and D and Analysis}

As mentioned in previous section, $\mathrm{C}$ and $\mathrm{D}$ are used to measure the differentiating effect of improvement of impact of accounting information on stock prices in big and small firms. The results of $\mathrm{C}$ and $\mathrm{D}$ are presented in Table 3.

Table 3. Panel C \& D Results Summary

\begin{tabular}{|c|c|c|c|c|}
\hline \multicolumn{5}{|c|}{ Panel F Results } \\
\hline & Intercept & $\mathrm{EPS}_{\text {it }}$ & BVPS $_{\text {it }}$ & $R^{2} \& \operatorname{Adj} R^{2}$ \\
\hline Coefficients & A & $\mathrm{C}$ & $\mathrm{B}$ & \\
\hline OLS & 804.93 & 7.6 & 1.6 & .89 \\
\hline Sig & $.001 * *$ & $.000 * * *$ & $.000 * * *$ & $.89 \mathrm{adj}$ \\
\hline FE & - & -3.06 & -.53 & .29 \\
\hline Sig & - & $.05 \because$ & $.01 *$ & .27 \\
\hline $\mathrm{RE}$ & 1196.23 & 6.81 & -1.31 & .65 \\
\hline Sig & $.01 *$ & $.000 * * *$ & $.000 * * *$ & $.56 \mathrm{adj}$ \\
\hline \multicolumn{5}{|c|}{ Panel E Results } \\
\hline & Intercept & $\mathrm{EPS}_{\text {it }}$ & BVPS $_{\text {it }}$ & $\mathrm{R}^{2} \& \operatorname{Adj} \mathrm{R}^{2}$ \\
\hline Coefficients & A & $\mathrm{C}$ & B & \\
\hline OLS & -279.37 & 28.58 & .66 & .84 \\
\hline Sig & $.05 ?$ & $.000 * * *$ & Not significant & $.84 \mathrm{adj}$ \\
\hline FE & - & 8.82 & -7.21 & .38 \\
\hline Sig & - & $.01 *$ & Not significant & $-.16 \mathrm{adj}$ \\
\hline $\mathrm{RE}$ & & 23.30 & .36 &. .43 \\
\hline Sig & $.000 * * *$ & $.000 * * *$ & Non significant & $.43 \mathrm{adj}$ \\
\hline
\end{tabular}

Signif. codes: 0 ‘***’ $0.001^{\text {'**’ }} 0.01^{\text {‘*’ }} 0.05^{\prime}$ '?

Source: Authors' construction from the output of R 
The results of panel regression on panels $\mathrm{C}$ and D indicate that the OLS method have produced the most acceptable results. The Adj $\mathrm{R}^{2}$ values of $\mathrm{C}$ and $\mathrm{D}$ are $84 \%$ and $89 \%$ which are very close to each other. In both the panel results, the coefficient of BVPS is biased towards zero and in one case it is negative as well. Though $\mathrm{C}$ and $\mathrm{D}$ are fragments of Panel B, but Adj $\mathrm{R}^{2}$ of $\mathrm{C}$ and $\mathrm{D}$ are .84 and .89 respectively while that of OLS output of $\mathrm{B}$ is $78 \%$. This occurs due to the consistency effect of the fragmented data.

All these results have guided us to draw some important inferences which are discussed in next section.

\section{DISCUSSION \& CONCLUSION}

The analysis and the findings of the previous section have led us to draw some important conclusions from this study.

The value relevance of accounting information in the era of new accounting standards is much enhanced than the pre adoption period. The $\operatorname{Adj} \mathrm{R}^{2}$ of the price regression model for the post convergence period is $78 \%$ which is in line with most of the European countries where it ranged from $52 \%$ to $84 \%$ after adoption of IFRS except Greece (Clarkson et al., 2011). The enhancement of value relevance (Adj $\mathrm{R}^{2}$ ) is $18 \%$. France, Germany and Netherlands have shown similar results as per the literature mentioned above. The study has also revealed that in Australia and UK, the Adj $\mathrm{R}^{2}$ did not change much while price regression model was applied on financial data based on local GAAP and IFRS-restated statements. This indicates for a minimum divergence between local GAAP and IFRS. One of the interesting observation of our study is that the local GAAP based accounting information, even in the pre-adoption era, could generate a substantial value relevance of accounting information in India which substantiates low level of divergence from the new standards.

The enhanced effect of value relevance of accounting information after the adoption of new standards on the big and small firms is almost similar. The difference in Adj $\mathrm{R}^{2}$ is only $5 \%$ while both the types of firms have revealed very high degree of association of accounting information with stock prices (84\% for big firms and $89 \%$ for small ones). This indicates that after the adoption of new standards, very high degree of symmetry has been achieved in the process of financial reporting and irrespective of firm-size a high degree of standardization has been achieved.

The challenges of adoption of IFRS based system in developing economies have been an important area of research (Sharma et al., 2017). The perception of professionals about adoption of IFRS in Singapore, Indonesia and Malaysia are elaborated in (Joshi et al., 2016). As an extension of research in the same line (Phan et al., 2018) have explained the important factors that had persuaded Vietnam to adopt IFRS based standards. Keeping all of these in mind, we think that the challenges, perceptions, driving factors and the actual empirical evidences in the post adoption period should be measured and the reasons for divergence or similarity with perceived challenges and expectations should be compared in a comprehensive study in ASEAN countries. This remains as a scope of further study in this area. The country-specific approach remains as a limitation of this study.

\section{REFERENCES}

Alali, F., \& Foote, P.S. (2012). The value relevance of international financial reporting standards: empirical evidence in an emerging market. International Journal of Accounting, 47(1), 85-112.

Avwokeni, J. (2018). On the value relevance argument: do the market participants pay a premium on future prospects of a firm?. Journal of Financial Accounting and Reporting, 16(4), 660-674.

Barth, M., Landsman, W.R., \& Lang, M. (2008). International accounting standards and accounting quality. Journal of Accounting Research, 46, 467-498.

Bepari, M.K. (2015). Relative and incremental value relevance of book value and earnings during the global financial crisis. International Journal of Commerce and Management, 25(4), 531-556. 
Clarkson, P., Hanna, J. D., Richardson, G. D., \& Thompson, R. (2011). The impact of IFRS adoption on value relevance of book value and earnings. Journal of Contemporary Accounting and Economics, 7(1), 1-17.

Cordazzo, M., \& Rossi, P. (2019). The influence of IFRS mandatory adoption on value relevance of intangible assets in Italy. Journal of Applied Accounting Research, 21(3), 415-436.

Filip, A., \& Raffournier, B. (2010). Value relevance of earnings in a transition economy: the case of Romania. International Journal of Accounting, 45(1), 77-103.

Gjerde, O., Knivsla, K., \& Saettem, F. (2011). The value relevance of financial reporting in Norway, 1965-2004. The Scandinavian Journal of Management, 27(1), 113-128.

Kadri, M. H., Aziz, R. A., \& Ibrahim, M. K. (2009). Value relevance of book value and earnings: evidence from two different financial reporting regimes. Journal of Financial Reporting and Accounting, 7(1), 1-16.

Harakeh, M., Lee, E., \& Walker, M. (2018). The effect of information shock on dividend pay out and dividend value relevance. International Review of Financial Analysis., 61, 82-96, https://doi.org/10.1016/j.irfa.2018.10.009

Joshi, M., Yapa, P.W.S., \& Kraal, D. (2016), "IFRS adoption in ASEAN countries: Perceptions of professional accountants from Singapore, Malaysia and Indonesia", International Journal of Managerial Finance, 12(2), 211-240. https://doi.org/10.1108/IJMF-04-2

Kim, S., \& Ryu, H. (2018). The impact of mandatory IFRS adoption on capital markets: evidence from Korea. International Journal of Accounting and Information Management, 26(1), 38-58.

Kumari, P., \& Mishra, C. S. (2020). Value relevance of aggregated and disaggregated earnings in India: significance of intangible intensity. Journal of Accounting, Auditing and Taxation, 39. https://doi.org/10.1016/j.intaccaudtax.2020.100321.

Lee, H., \& Lee, H. (2013). Do Big 4 audit firms improve the value relevance of earnings and equity?. Managerial Auditing Journal, 28(7), 628-646.

Okafor, O.N., Anderson, M., \& Warsame, H. (2016). IFRS and value relevance: evidence based on Canadian adoption. International Journal of Managerial Finance, 12(2), 136-160.

Onali, E., Ginesti, G., \& Vasilakis, C. (2017). How should we estimate value relevance models: insight from European data. The British Accounting Review, 49(5), 460-473.

Phan, D., Joshi, M., \& Mascitelli, B. (2018). What influences the willingness of Vietnamese accountants to adopt International Financial Reporting Standards (IFRS) by 2025?. Asian Review of Accounting, 26(2), 225-247. https://doi.org/10.1108/ARA-03-2017-0052

Sharma, S., Joshi, M., \& Kansal, M. (2017). IFRS adoption challenges in developing economies: an Indian perspective. Managerial Auditing Journal, 32(4/5), 406426. https://doi.org/10.1108/MAJ-05-2016-1374 
Thijssen, M. W. P., \& Latridis, G. E. (2016). Conditional conservatism and value relevance of financial reporting: a study in view of converging accounting standards. Journal of Multinational Financial Management, 37-38, 48-70.

Veith, S., \& Werner, J. R. (2014). Comparative value relevance studies: country differences vs. Specification effects. The International Journal of Accounting, 49(3), 301-330.

\section{Copyrights}

Copyright for this article is retained by the author(s), with first publication rights granted to the journal. This is an open-access article distributed under the terms and conditions of the Creative Commons Attribution license (https://creativecommons.org/licenses/by/4.0). 